DOI: $10.17516 / 1997-1370-0600$

УДК $37.032+316.6$

\title{
Compensatory Role of Symbolic Mediators in Constructing Ethnocultural Identity
}

\author{
Yuliya N. Avdeeva, Kseniya A. Degtyarenko* \\ and Natalia P. Koptseva \\ Siberian Federal University \\ Krasnoyarsk, Russian Federation
}

Received 10.03.2020, received in revised form 30.04.2020, accepted 12.05.2020

\begin{abstract}
The article studies the problems of cultural identity under the conditions of modern global transformations. Approaches of foreign and Russian researchers are analysed presenting both negative and positive assessment of hyperdynamism of modern development in terms of personality formation. The article provides the analysis of the phenomenon of 'culture historicising', which reflects the importance of turning to the origins in order to overcome the problem of alienation, loneliness, increasing gap with the past and loss of the continuity of generations. The theory of compensation and the theory of memory are considered herewith as they offer specific cultural forms of history representation and play an important role in the formation and maintenance of the ethnocultural identity.
\end{abstract}

Keywords: ethnocultural identity, cultural universalism, symbolic mediators, compensation theory, culture historicising, globalisation, memory theory, museumisation.

The reported study was funded by RFBR, project number 19-39-90012.

Research area: culturology.

Citation: Avdeeva, Yu.N., Degtyarenko, K.A., Koptseva, N.P. (2020). Compensatory role of symbolic mediators in constructing ethnocultural identity. J. Sib. Fed. Univ. Humanit. Soc. Sci., 13(5), 702-715. DOI: $10.17516 / 1997-1370-0600$.

\footnotetext{
(C) Siberian Federal University. All rights reserved

* Corresponding author E-mail address: yulia-avdeeva2406@mail.ru, akseniya.krupkina@mail.ru, decanka@mail.ru ORCID: 0000-0003-3910-7991 (Koptseva)
} 


\section{The concept of cultural universalism: followers and critics}

With the beginning of the modern era and further rapid sociocultural and technical development in the field of the humanities, a significant rethinking of reality, the role of the individual and the role of the state in society took place, new forms of life and methods of understanding the world began to develop. There are many responses to the processes of globalisation and hyperdynamism of the culture development in the scientific community, controversial points of view, critical positions and proposals for stabilising public life in the current cultural conditions. The statement of Odo Marquard, who had a great influence on cultural policy and the intellectual climate in Germany, is quite illustrative: "The more modern the modern world becomes, the more necessary the humanities become" (Rumyantseva, 2016).

One of the dominant positions today is the destructive reaction to the rapid development and over-rationalisation of modern culture based on the loss of a person's identity, orientation in a complex reality and synchronism of human consciousness. Today, an increasing number of researchers point to the crisis of modern culture, expressed in the development of cultural universalism: everyday life in modern society is routinised, has a unified, standardised and complex character, where a person experiences problems with the orientation system, identity and loneliness.

The problem of overcoming all kinds of dogmatism and political idealism, human alienation to the world and maintaining continuity with its cultural and ethnic heritage is becoming ever more acute for modern society. An individual, by virtue of even anthropological features, cannot exist in this super-rationalised reality, which is separated from the historical context, deprived of its historical and cultural heritage.

In the context of post-modern social instability, the problem of identity is becoming one of the key ones. Global transformations entailing cultural and political pluralism, detraditionalisation, religious polytheism, an extensive set of sociocultural patterns of be- haviour, and alternative choices have led people to many difficulties. Under the conditions of cultural relativism, a person loses orientation and ability to determine the main thing in the environment and in their own inner world. In the public consciousness, any hierarchy of cultural values has collapsed, all cultural patterns and values have become equivalent (Leskova, 2009).

Karl Rosencrantz in his essay "Progress in the Uniformity of Our Civilization" in his own way reveals the processes of globalisation of the modern world and says that civilisation is absolute McDonaldisation: everything is brought to uniformity, all the elements of society's life become standardised and unified. Fashion, games, means of transport communication, sports, armament of the armies of various states, government structures, means of communication and modern media, even tame animals and plants - all of that becomes uniform and this uniformity goes beyond any borders.

Representatives of the "Philosophy of Life" also critically consider modern European culture and call it a culture of barbarism, where science serves the ideas of political domination, destruction and nihilism with typical features of massive involvement, religiosity, spreading of socialist ideas that subordinate an individual to society. The concept of 'civilisation' means the stage of decline, the death of culture. F. Nietzsche blames modern culture for following the tradition of the Socratic principle. It is in a deep crisis due to the predominance of rationalism over life, over instincts and, as a result, over human freedom: "It was not the Athenians who killed Socrates, it was he who established the dictatorship of reason, offered Athens a bowl of poison" (Nietzsche, 1990). These ideas have been developed in this sense, the opposition to rationalism and materialism is increasing in favour of the development of individuality, based on a strong-willed principle, on instincts that have a direct impact on the dynamics of culture. The dominance of reason ultimately leads to the formation of masses blindly following behavioural stereotypes, familiar landmarks, where an individual becomes controlled and lives like in a 'labyrinth'. 
In modern culture, person's identity is multiple and changeable. People play many social roles every day. Many scientists emphasise the negative side of such a multiplicity. E. Fromm wrote that "a person can play many roles and be subjectively certain that each of these roles is the main one. In fact, a person plays every role in accordance with their ideas about what others expect from them; and for many people, if not most, the true identity is completely stifled by pseudo-personality" (Fromm, 2007). W. Dilthey, referring to the problem of personal identity in modern society, also emphasises that, in the final analysis, out of the whole set of roles, a person is not completely included in any of them. "Individuals are not included in the complex of influences in their entirety" (Dilthey, 2004). K. Marx paid particular attention to the topic of alienation, which was a specific ethnic core, the pathos of Marxist criticism of capitalism, saying that "the work of a worker is not their self-activity. It belongs to another, the workers lose their inner self" (Marx, 1974), that is, a person does not participate in it as a person. Marx sees the solution to the problem of alienation in a person's ability to freely change roles.

A famous Russian culture studies specialist V.A. Kurennoy, comparing the processes of identification in traditional and modern culture, indicates that in a traditional society people are whole, their identity is total. At the same time, in the modern culture of 'insecurity', a person needs to be ontologically guaranteed something. In this sense, Kurennoy places special emphasis on segmented identity as the most necessary one for each individual, in order to build their private life in a world where there are no traditional rules and rituals.

D.N. Shul'gina (Shul'gina, 2010) notes that the big blow of modern hyperdynamism falls on the culture in which there are deep qualitative transformations: a change in value orientations, criteria for assessing life satisfaction, absence of stable ideals, and illusory nature of the future. The author states that the sociocultural space of identities is rapidly expanding, resulting in rapprochement with what was previously 'alien'. Globalisation creates conditions for alienation from the original 'self' and is not at all in favour of assimilating the best of the 'alien'. The boundaries between cultures are blurred, and universalism and standardisation are spreading among different sociocultural communities. There is a transformation of the cultural core that consists of traditions, language and worldviews. Herewith, global changes influence the structural elements of the entire cultural system. This results in subordination of all local cultures to one common basis. They adapt not to one another, but to a metalanguage. Thus, the deformation of traditional attitudes, which are the core of human identity, leads to an inevitable crisis and collapse of sustainable communities.

Shul'gina pays special attention to the process, which she designated as 'detraditionalisation' of society. In modern society, traditions coordinate their status and significance, they lose their sacred character. We are talking about the decline of the sociocultural influence of tradition, removal of traditional values, patterns of behaviour and life styles to the periphery of society, their marginalisation. The ascriptive connections of the individual with the family, living space, and social background are weakened.

The functions of tradition are replaced by surrogate 'substitutes' in the form of products of mass culture, role of the media, various social organisations, religious movements, consumer ideology, etc. People begin to see traditions as a set of prejudices, superstitions, unverified information, entrenched in the experience of past generations and requiring its verification in modern conditions.

In the context of the mentioned problems, it would be appropriate to recall the acute statement of E. Giddens: "Tradition deprived of content and subjected to commercialisation, turns into either a part of historical heritage or kitsch trinkets from a souvenir shop at the airport" (Giddens, 2004). Thus, tradition begins to be perceived as an artificial limitation of a person's free expression, rather than concentration of cultural experience of generations. When traditions lose their force and the free choice of lifestyle prevails, this cannot but affect the individual's sense of being a personality. Traditions become not the basis of a per- 
son's passive perception of already established, rigidly fixed attitudes, values and stereotypes, but a component of an extremely diverse, pluralistic information space.

If in traditional societies the cultural tradition covered an individual setting them free from numerous situations of personal choice and responsibility, then modern societies are developing radically differently. It turns out that a person belongs to various sociocultural realities, fulfilling only a part of their personality in each of them.

In culture, the identity and continuity of the development of society are coded, and cultural identity, in turn, provides a person with continuous, lasting confidence, security, ability to predict social situations, uniqueness of one's own position in society. This means that radical changes in this area have the most traumatic consequences. Piotr Sztompka called this situation of traumatic changes 'cultural trauma' (Sztompka, 1996). Among the social consequences of the 'cultural trauma', he emphasises the lack of trust in social institutions and other people; feeling of powerlessness, passivity, apathy; focus on today and reduction of longterm goals and objectives; a complex of fears, an uncertain state of anxiety, a tendency to believe myths; cultural disorientation, uncertainty about which patterns should be followed by a person's own behaviour, what values are dominant.

Like P. Sztompka, Z. Bauman (Bauman, 2008) considers one of the main reasons for social instability to be the refusal of people to achieve long-term goals and objectives, that is, a radical change in the value system. People prefer the short-term perspective of planning their own activities, as a result of which the continuity of generations is destroyed, the value of family traditions and values is reduced. The category of short-term planning devalues the concepts of trust, fidelity, devotion to any relations, phenomena, objects.

P. Berger and T. Luckmann (Berger, 1995) also point to the problem of losing the individual's orientations in modern social space. They attribute this to social disorganisation and individualisation of society, which violates interpretative patterns of human behaviour. It is important for an individual that there is a significant probability that unfamiliar people in a typical everyday situation will behave in the expected manner, since the nature and principles of constructing their interpretative schemes are the same. Thus, an understanding of the events and actions of others does not arise as a result of a person's individual work to create values, but as a result of 'adoption from the other' of the world in which 'others' already live.

Speaking about postmodern culture, A. Flier and W. Welsch (Flier, 2000; Welsch, 1992) talk about cultural pluralism, relativism, conventionality of cultural norms, and absence of a visible framework of ethnic traditions and restrictions. That is, the modern picture is composed of a mosaic of historically local cultures, the identity and system of which has a random, heterogeneous, unstable and phantom character. Moreover, A. Flier raises the problem of the formation of "a new sociocultural identity of a citizen of modern society" and introduces the concept of "cultural competence of an individual". The task of forming the latter is imposed on education and national politics. Flier sees a positive trend in the emerging new (national) type of society and culture: in the process of human life, the role of religious, estate and other restrictions significantly decreases, they are replaced by more active implementation of creative and labour abilities, there appears free competition of 'self-fulfilling personalities', growth of scale and dynamics of the information transmission, spread of universal literacy, democratisation of self-government processes.

Several researchers from Russia address the topic of the sociocultural crisis: L. Ionin (Ionin, 2008), V. Yadov (Yadov, 2006), S. Klimova (Klimova, 2000), A. Dugin (Dugin, 2008). They put the crisis of identity at the forefront, which for Russia is the result of not only global transformations in the world system, but also qualitative regional changes. After the collapse of the USSR, a radical reform of society and its main institutions took place, which is considered to have caused the value-worldview and structural uncertainty at the personal, group and social levels.

The concept of A. Dugin is especially interesting within the framework of this work, as 
it is based on a specific line of development and transformation of identity. The author says that identity develops along the lines of pre-modernity, modernity and post-modernity. Empire, ethnos, religion and hierarchy are the identities that correspond to the first period. The process of the second period is characterised by the identity of the state, nation, secularism and equality of individuals. The situation of postmodernity reveals new identities to us in the form of globalisation (unlike classical bourgeois states), individual myth-making (unlike the setting for secularity), planetary cosmopolitanism (unlike nations). Speaking about postmodernism, the author considers it to be an era of ultra-individualism, which developed as a result of endowing one's virtual self with arbitrary qualities projected onto cyberspace.

The main identity of postmodernity is the 'humanity' where individualism reaches its critical limit. Any identity implies the 'friend or foe' principle, but in the modern era, a person becomes so autonomous that they generally lose the sight of the 'foe'. A person exists among many inconsistent worldviews, languages, discourses, they are free to believe in anything and identify themselves with anything. A person has no spiritual limitations, but there are no guidelines either. Moreover, Dugin points out that postmodern people are getting more and more inclined to possess a game identity due to the increasing inclusion of their life, work and leisure activities in virtual worlds. Thus, the human 'self' dissolves in a dubious fragmentary existence, which is exacerbated by an expanding addiction to drugs and contributes to the existential nature of life. As a result, instead of any kind of social integration (civil or hierarchical), we get the prospect of developing an 'individual delusion'.

Meanwhile, Dugin draws attention to the fact that in the transition from modernity to postmodernity, abandoned and forgotten attitudes of 'traditional society' reopen. No matter how paradoxical this may sound, but archaic identities keep reminding of themselves: for example, the term 'empire' is again used in the political science; ethnic communities again remind of themselves after centuries of depression by nation states; religions again become a condition of world real politics; radical political organisations and sectarian movements reproduce the specificity of ancient hierarchies.

In the context of the above-described problems of modern society, researchers pay special attention to individual cultural creation (Tul'chinskiy, 2002). Each individual should be active in social life, thus fulfilling their cultural and historical mission. Such cultural development should be the task of not only creative personalities (superhuman, according to Nietzsche), not of a person in general, but of a specific, individually defined person. This is due to the fact that it is the culture that is the key area on the way to self-affirmation, self-fulfilment and recognition by society. It is the culture that sets life-meaning values and models of people's activity, behaviour and communication.

Therefore, it is typical for our era that completely different, conceptually conflicting identities can manifest themselves under its conditions. We can find in the same plane traces of all paradigmatic eras, which are not localised in modern space clearly enough: fragments of pre-modernity and modernity can be found in the post-modern West, and post-modernism, in turn, can penetrate the archaic social spaces of the East and the Third World. In this transient, fragmented existence, with its endless stream of changes and knowledge, a person needs to fix, crystallise specific historical knowledge with the help of cultural forms, allowing them to take root in their community, feel their belonging to it, have a reliable support, a stable system of values and orientations, and, of course, maintain the continuity of generations.

\section{Historicising culture as modern academic and everyday practice}

After the culture of reason typical for the Enlightenment era (having spread not only in the field of science, but also in culture, aesthetics, art and philosophy), the universal implantation of rationalistic ideas and unhistorical thinking, noticeable qualitative changes take place in the sociocultural environment of the civilised society. The origins of the new European culture start with the ideas of history as something connected exclusively with remnants, delusion, erroneous opinion. However, 
with the era of modernity, a new understanding of the world comes, within which the interest in a deep understanding of historicity is revived, history is understood as what makes us individual.

For modern society, in contrast to traditional society, historical consciousness is characteristic: the further we move away from the past, the greater the need becomes to find our uniqueness there. Even the Baden school of neo-Kantianism put the historical (ideographic) method at the head of the cognitive process, because, unlike natural science, it does not go away from the individual characteristics of the subject, does not select the universal. Neo-Kantians also point out that it makes no sense to strive to comprehend all aspects of reality, because in this case cognition is impossible, since reality is infinite. In this context, school representatives were the first to thoroughly research the concept of 'values' and became the founders of axiology. If we look at the current sociocultural situation from this point of view, we can see that this situation continues to exist: an individual and society as a whole lose themselves in an endless stream of changes in this incomprehensible reality, they cannot get to know themselves, feel safe and confident, because there are no values, no sense of belonging to something. Moreover, personal identification becomes the subject of numerous interpretations from various social institutions that try to 'recommend' certain value systems and norms of behaviour.

The further people move away from the past, the more they indulge in illusions. Past experience accumulated by people is becoming less and less a future experience, i.e. in the future its source remains scarce, due to the intensive dynamics of development. The world is losing its character of continuity, the expectation of the future is less and less controlled by experience, and this turns people into 'waiting' dreamers. O. Marquard calls modern people 'children' who have stopped growing up because they live in the age of 'alienation to the world'. This means that the great speed of the appearance of more and more innovations leads to the fact that more and more phenomena are rapidly becoming obsolete. This happens with our experience, because in everyday reality the situations for which we gained this experience become less and less common. Therefore, instead of becoming an independent 'adult' in the course of constant layering of experience, a person is increasingly thrown back to the unknown, new, alien world. According to Marquard, experience is the only way to overcome the alienation to the world.

Political conservatism and the romantic movement ('political romanticism') are at the forefront (Mannheim, 1991; Schlegel, 2015; Görres, 1987). Edmund Burke (Burke, 1993), criticising the revolutionaries (referring to the French Revolution) for completely casting aside the past, writes that "you chose to act like you had never been a civilised society and you had to start it all over again. You got sick because you started with contempt for everything that belonged to you. You started trading without capital. ... Honouring your ancestors, you would learn to honour yourselves".

Moreover, knowledge and understanding of history is seen as liberation. Theorists of historicism indicate that we ourselves are a product of history, which means that, having discarded the past, we will not come to an understanding of ourselves. V. Dilthey summarised this position by saying that "history makes us free, since it exalts us above the conditioning of views arising in the course of our lives". Thus, realising the historical random nature of our views, we can free ourselves from them, which is an important condition for modern democracy.

Later, in the framework of the compensatory theory formulated by J. Ritter, history and historical sciences about culture became a necessary element of the modern world. This theory rejects criticism of civilisation and argues that only civilisation - global, universal, impersonal and standardised - is a condition that interest in history will appear in our society. The relations of civilisation and culture are being revised: as the civilisational dynamics of modernity accelerate, the number of local cultural relics is growing. That is, the demand for local cultural identity is growing not contrary to, but due to the expansion of the global standardised civilisation. Civilisation creates the 
conditions for interest in our own culture. If we live locally, we ourselves are not aware of the historical value of what we have.

Moreover, as O. Marquard notes, the faster the changes occur, the more a person needs those life skills that are guided by cultural customs: "people do this because they have been always doing that". That means that the more extreme the life situation is, the more important it is for people to have such skills, accepted forms of behaviour and traditions. These very 'habits' are also gaining importance because they have the ability to free from the illusions which a person is overwhelmed with in a changing world.

Concluding the review of studies on the problems of contemporary cultural development, it is worth noting one of the recent publications by V. Kurennoy "Borders in a Limitless World" (Kurennoy, 2018), where he speaks of two opposing development trends and their possible dialectical existence. He says that all existing theories in one way or another come down to the fact that the modern era appears as an erasure of borders that extends to absolutely all systems (civil equality, a unified system of law, a unified tax system, uniform document management, capitalist economy, where money is a universal means of mediating any exchanges, progressive rationalisation and McDonaldisation of society) (Rittser, 2011).

On the other hand, paradoxically, Kurennoy writes about the reverse trend of boundaries' production, which in classical cultural philosophy is usually called culture. "Not a single epoch has generated as many boundaries as the modern one": fragmentation and increasing pluralisation are experienced by all spheres of society's life. This may include the increase in the number of states, various religious movements, replenished with quasi-religious belief systems, and a truly explosive increase in the number of borders falls precisely on culture. A whole industry is being formed to generate these various borders: tourism, gastronomic tours, the invention of local stories, 'places of memory' and their 'geniuses of place'. That is, while the civilisation not being tied to local history and a certain territory, is gaining momentum in the world system, the demand for the formation of boundaries and differences related to locality and history of origin is becoming more and more active. People strive to maintain and emphasise their identity, crossing the border of their locus. Thus, the construction of a local identity is as much an integral part of modernity as spreading of McDonalds. Social networks, for example, are introducing more and more new tools to create an individual profile that allows us to demonstrate our personal history, emphasise our differences and draw borders.

Kurennoy notes that for the successful development of society in the modern civilised world, a balance between civilisation and culture is necessary. There is nothing wrong with the fact that in everyday life today we choose the products of civilisation, as it is progress. Not in a lofty enlightening sense, but in the ordinary one: it is comfortable for our existence. Meanwhile, civilisation gives us a sense of alienation and leads to the loss of any kind of identity. It is precisely with the help of culture that a balanced existence of civilisation can be achieved: through the production of cultural, historical and cultural borders, attention to historicism, regionalism, to one's own local identity.

Thus, the wide range of problems highlighted by modern scholars includes cultural and political pluralism, alienation, loss of orientation and identity, detraining, 'loneliness in the crowd', blazoning, endless change in sociocultural conditions, synchronised consciousness of mankind, McDonaldisation, trends of overall development of universalism and blurring the boundaries between 'friends and foes', crystallisation of culture. All this forces modern society to seek compensation through the preservation of the past, which is permanent and historical in nature: museums, conservatories, archives, reconstruction with the help of archaeology, history, etc.

The compensation theory, which is of great importance for preserving the identity, has already been mentioned and offers specific compensatory ways for overcoming the negative consequences of the hyperdynamic development of modern society. It makes sense to dwell on it in more detail for further 
understanding of which forms and categories represent history, and what role they play in the formation and maintenance of ethnocultural identity.

\section{The compensation theory of culture}

The development of the compensation theory started in the second half of the $20^{\text {th }}$ century. The very concept of 'compensation' gained the greatest fame and popularity in Germany in the 1970s.

The compensation theory is associated with the name of Joachim Ritter. He was the student of E. Cassirera, author and editor-in-chief of the "Historical Dictionary of Philosophy" (1971-2007). J. Ritter, having created the Collegium Philosophicum in Münster, brought together various scholars who were close to his understanding of modernity. Among them were H. Lübbe, O. Marquard, R. Spaemann, G. Rohrmoser (Plotnikov, 1994). Often, in the framework of the conversation about the Ritter School, the political discussion of the latter with the Frankfurt school is of great importance within the framework of the theory of modernism.

J. Ritter considers the phenomenon of 'bifurcation' of the space of modernity between the past and the future to be one of the main features of modernity, which was for the first time revealed to the world by the Great French Revolution. In the framework of the theory of modernity, J. Ritter sees the main importance of historical development in human freedom, and the main reason for the duality of modernity is the 'historical orientation of modern institutions' (Rumyantseva, 2017). The modern world carries the problem of disorientation (crisis of orientation), the lack of necessary guidelines which a person can rely on in performing their activities. Speaking of historical orientation, the answer to the crisis of orientation is the conservation and updating of the past.

The compensation theory by Hermann Lübbe and Odo Marquard, which has also been criticised by supporters of the Frankfurt School, suggests compensation for the negative effects of modernity through the development of social, cultural and educational spheres. Thus, the distinguished spheres, 'sciences of the spirit', fulfil the spiritual need of society through compensation for the reality that is constructed by modernisation, providing the modern man with an opportunity to be included in the process of historical individualisation. In this sense, the position of $\mathrm{H}$. Lübbe is interesting, who, in continuation of the concept of J. Ritter, speaks of the great importance of the narrative component of history, rather than theoretical one.

Dynamic civilisational development causes an increase in the number of relics of the recent past, outdated and beyond the usual (H. Lübbe defines this situation with the concept of "relict growth"). Thus, modern society, increasing the scope of innovation, leaves behind an array of past experience that no longer meets the needs of the present. In the process of the constantly accelerating present, a person faces the problem of losing clear self-determination, self-understanding. As a result, conservative actions are born, as a response to the accelerating progress. They do not reject the latter, but form some kind of slowdown opportunities that can help a person cope with the stream of innovations. A growing number of museums, organisations for the protection of historical and cultural monuments, restoration work are meant to compensate for the progressive civilisational development through the prism of historical consciousness. Through the creation of museum values, a person shows a desire to preserve their own identity. "Museums and interest in personal stories are two different manifestations of the same process: a compensatory reaction to the world that is changing too fast" (Rumyantseva, 2015a). All this happens in a situation of danger of the identity dissolution in a constantly transforming modernity.

In the situation of the informational glut of modern culture, the necessary historical knowledge is selected for future generations. $\mathrm{H}$. Lübbe defines this phenomenon of modernity with the term 'preception' (Präzeption).

Aleida Assmann, arguing in the framework of finding new meanings of the temporal mode of modernity, relies on two theories that produce a new look at the constantly transforming modernity: the theory of com- 
pensation developed by J. Ritter, H. Lübbe and $\mathrm{O}$. Marquard, and the theory of memory, which differs from the first one by understanding of the past.

In the context of the theory of memory, the past does not disappear irrevocably, but is exposed to finding new meanings within the framework of a new round of social development, "as departed, disappeared and lost, it can always be returned, presented and preserved" (Assmann, 2017). A. Assmann identifies the debatable, traumatic events of past years as the most significant objects for reconsideration.

A. Assmann also considers which forms allow to represent history, outlining narrative, displaying and staging:

1) building a certain chronology of events, the narrative shows cause-and-effect relationships between events, and fulfils itself in the text. The author emphasises that narratives can be classified according to the type of plot: "a story of origin, conversion to a new faith, a novel of upbringing or formation, etc." (Assmann, 2019). The narrative can be found in other forms of historical representation - displaying and staging, which is a way of structuring the eventual and semantic component;

2) displaying involves the placement of historical artefacts in space, which can be a text, an image or an object. The fundamentals of organisation of space rely on the narrative basis, but when it comes to objects and images endowed with unique non-verbal specifics, a special semantic component of space ordering appears;

3) in the framework of such a representation form as staging, A. Assmann distinguishes between "media staging" and "spatial staging". In the first case, it is a story presented in moving images, cinema, television or digital media. In the second, it is reconstructing actions taking place on a specific site, prepared for stage production, which at the same time is a historical place and carries a memory of a real event of the past. Religious buildings, castles and rural areas, memorial sites, concentration camps serve as an example of such historical loci, and the preserved relics of the past allow you to immerse yourself in this memorial atmosphere of a certain historical period. These memori- al sites are used for filming, museum spaces, archives, research centres are organised there (Assmann, 2019).

The above statements give us an idea of the extent to which modern society needs some moderation, compensation for the rapidly changing present, structuring of the recent past and maintaining a holistic view of itself.

Modern man is interested in the restoration and preservation of their identity and the fundamental role in this process is played by symbolic mediators as carriers of cultural memory, which in turn represents a model for the transfer of cultural meanings, knowledge about the past, their recreation, accumulation and actualisation. The space of cultural memory is a certain community of people that identifies itself through symbols, artefacts of the past that have no time boundaries. Storage facilities for cultural memory are museum spaces, archives, libraries, films and literature, etc. The cultural memory is broadcast through rituals and traditions. Symbolic mediators are a kind of "collective symbolic construction, the functioning of which is ensured by social communication and assimilated by the memory of individuals" (Assmann, 2018). As a result, memory is formed using signs with memorial meaning and symbols.

The rapid changes of modern time did not pass by local and already vulnerable ethnic cultures of indigenous peoples. The unifying impact of global processes exacerbated the problems of cultural, social and spiritual revival, which results in the loss of ethnic certainty, marginalisation and erasing of ethnic boundaries. The practice of preserving the culture, native language, traditional forms of management, and indigenous beliefs has become a global problem that requires certain institutional conditions to protect the rights and interests of indigenous people, both at the state and regional levels.

Religions of indigenous peoples are mistakenly understood as primitive, as a gross manifestation of primitive consciousness, devoid of deep feelings. Many scholars focus their attention on the study of world religions, but they have no idea about the rich symbolism and depth of the picture of the world of 
local ethnic religions. This has led to the loss of a number of myths and legends, ritual ceremonies, not only revealing their traditional culture, but also providing answers to 'eternal' universal human questions. The essence of the worldview of indigenous peoples is that any actions that fill the human life, have great value and significance not themselves, but as a repetition of an ideal, mythological model. This repetition is revealed to us in the form of a ritual. Many researchers show their interest in considering the specific features of the religion of the indigenous peoples of the North (Tokarev, 1976; Pospelova, 2000), in particular, the reconstruction of an integral idea of religious consciousness in the process of cultural transformations (Avdeeva et al., 2019a, 2019b; Zamaraeva et al., 2019).

Currently, much attention is paid to the processes of preserving the languages of the indigenous peoples of the North and various attempts are being made to recreate them (Koptseva, 2014, Koptseva and Reznikova, 2015). In particular, for a long time, the system of 'language nests' has been actively operating in the northern regions of the Russian Federation (Dolzhenko, Bayanova, 2016; Reznikova, 2015) as part of teaching indigenous languages, with immersion in the language environment primarily of children of preschool and primary school age. Researchers of the Krasnoyarsk Krai study the linguistic problems of small indigenous peoples living compactly in the north of the Krasnoyarsk Krai, in particular, the possibility of reconstructing the language: in 2018 the group of scientists led by N.P. Koptseva implemented the Evenk Language Revival Research Project, in 2019 the Project Office for the Development of the Arctic and Siberian Federal University launched joint scientific activities to create the Enets written language (http://энцы.pф/).

The appeal to the cultural landscapes of the indigenous peoples of the North, as a form of museumisation of culture (Kimeev, 2008) and having great symbolic significance, also develops and appears in the allocation and study of sacred places (Balalaeva, 1999; Novikova, 2013), the space of ecomuseums (Gnedovskiy, 1994; Korostina, 2000; Kimeev, 2008), ethno- graphic parks (Ol'zina, 1997), including places of traditional nature management (Krasovskaya, Tul'skaya, 2013).

Therefore, unstable processes occurring during global changes cause the demand of modern society for historicising and crystallising of their own local culture. Preserving the culture and ethnocultural identity of indigenous peoples is one of the most difficult tasks, since it is a question of preserving the ethnographic content of culture (folklore, traditional forms of management, traditional holidays, crafts and art, language). The most effective compensatory practices for the revival and preservation of indigenous cultures are practices for creating a network of special museums or other ethnographic centres; formation of the registers of intangible cultural heritage of indigenous peoples in a number of constituent entities of the Russian Federation; providing opportunities to engage in traditional activities (reindeer herding, fishing and hunting); the formation of the political and economic elite of ethnocultural groups that play the role of representatives of their community and integrate into urban political culture. Moreover, an interesting practice for ethnocultural groups themselves is turning to the results of scientific research of their own culture, as a kind of tool for the formation of self-identification of indigenous peoples.

\section{Conclusion}

Constructing the ethnic identity of the indigenous peoples of the North and Siberia is being studied today in the following areas:

1) ethnographic descriptions that use the classical methodology are based on field research, including longitudinal studies with an interval of 10 years;

2) analysis of complex ethnic and cultural processes that are typical for the modern period of ethnic history, the use of constructivism as the basic methodological approach;

3) identification of individual phenomena characteristic of the ethnic construction, their study during field research using high-quality methods of social research.

Currently, traditional ethnographic studies coexist in the same research space with 
constructivist analyses. There is a possibility that in the future an integrated approach will be found combining the strengths of both tradi-

tional and constructivist methodologies.

\section{References}

Assmann, A. (2017). Raspalas'sviaz' vremen? Vzlet i padenie temporal'nogo rezhima Moderna [Has the connection of times broken up? The rise and fall of the temporal regime of Art Nouveau]. Moscow, Novoe literaturnoe obozrenie, $272 \mathrm{p}$.

Assmann, A. (2018). Dlinnaia ten' proshlogo: Memorial'naia kul'tura i istoricheskaia politi$k a$ [Long shadow of the past: Memorial culture and historical politics]. Moscow, Novoe literaturnoe obozrenie, $328 \mathrm{p}$.

Assmann, A. (2019). Zabvenie istorii-oderzhimost' istoriey [Oblivion of history-obsession with history]. Moscow, Novoe literaturnoe obozrenie, 552 p.

Avdeeva, Y.N., Degtyarenko, K.A., Koptseva, N.P., Pchelkina, D.S., Shimanskaya, K.I., Shpak, A.A. (2019a). Spetsifika religioznogo soznaniia ketov i sel'kupov v kontekste kul'turnogo $\mathrm{i}$ istoricheskogo razvitiia [The specificity of religious consciousness and culture in the context of cultural and historical development]. In Severnye arhivy $i$ ekspeditsii [Northern Archives and Expeditions], 3 (3), 63-80.

Avdeeva, Yu.N., Degtyarenko, K.A., Pchelkina, D.S., Shimanskaya, K.I., Koptseva, N.P., Shpak, A.A. (2019b). Religion of the selkups and the kets in the historical and cultural genesis. Zhurnal SFU. Gumanitarnye nauki [Journal of SibFU. Humanities \& Social Sciences], 12 (5), 726-751.

Balalaeva, O.Ye. (1999). Sviashhennye mesta khantov Sredney i Nizhney Obi [Sacred places of the Khanty of the Middle and Lower Ob]. In Ocherki istorii traditsionnogo zemlepol'zovaniia khantov (materialy $k$ atlasu) [Essays on the history of the traditional land use of Khanty (materials for the atlas)]. Ekaterinburg, 139-156.

Bauman, Z. (2008). Tekuchaia sovremennost' [Fluid modernity]. Saint Petersburg, 240 p.

Berger, P. (1995). Sotsial'noe konstruirovanie real'nosti: traktat po sotsiologii znaniia [Social construction of reality: a treatise on the sociology of knowledge]. Moscow, Mosk. filos. fond 'Akademia Centr', Medium publishing centre, $334 \mathrm{p}$.

Burke, E. (1993). Razmyshleniia o revoliutsii vo Frantsii [Reflections on the revolution in France]. Moscow, Rudomino.

Dilthey, W. (2004). Postroenie istoricheskogo mira v naukakh o dukhe [The construction of the historical world in the sciences of the spirit]. In Sobranie sochineniy [Collected Works]. Moscow, Tri kvadrata, 3, 10-413.

Dolzhenko, S.G., Bayanova, E.V. (2016). 'Iazykovoe gnezdo' kak sposob resheniia problemy ischeznoveniia iazykov korennykh malochislennykh narodov Severa ['Language nest' as a way to solve the problem of the disappearance of the languages of the indigenous peoples of the North]. In Filologicheskie nauki. Voprosy teorii i praktiki [Philological Sciences. Questions of theory and practice], 6(60), II, 191-193.

Dugin, A. (2008). Evoliutsiia sotsial'nykh identichnostey pri perekhode k paradigme postmoderna [Evolution of social identities in the transition to the postmodern paradigm]. In Informatsionno-analiticheskiy portal EVRAZIJa.orgg. Available at: http://www.evrazia.org/modules. php? name $=$ News\&file $=$ article $\&$ sid $=\% 201979$

Enetskaia pis'mennost' (2019). Available at: http://энцы.pф/ (accessed 1 March 2020).

Flier, A.Ja. (2000). Kul'turnaia kompetentnost' lichnosti: mezhdu problemami obrazovaniia i natsional'noi politiki [Cultural competence of an individual: between the problems of education and national politics]. In Obshchestvennye nauki i sovremennost' [Social Sciences and the Present $], 2,151-165$.

Fromm, E. (2007). Begstvo ot svobody [Escape from freedom]. Moscow, Izdatel'stvo «AST», 383 p. 
Görres, J. (1987). Estetika nemetsikh romantikov [Aesthetics of German romantics]. Moscow, Iskusstvo, 345.

Giddens, Ye. (2004). Uskol'zaiushhiy mir: kak globalizatsiya meniaet nashu zhizn' [An elusive world: how globalization is changing our lives]. Moscow, Ves' mir, 116 p.

Gnedovskiy, M.B. (1994). Tainy pod otkrytym nebom: (Muzei v Var'egane) [Secrets under the open sky: (Museum in Variegan)]. In:Mir muzeia [World of the Museum], 3, 8-19.

Ionin, L.G. (2008). Sovremennaia kul'tura Rossii [Modern culture of Russia]. Moscow. available at: http://www.gumer.info

Kicheeva, K.A., Starko, E.A., Reznikova, K.V. (2015). Politiko-pravovye osnovy kul'turnykh vzaimodeistviya severnykh narodov Rossiiskoi Federatsii: istoriia i sovremennost' [Political and legal foundations of cultural interactions of the northern peoples of the Russian Federation: history and modernity]. In Sotsiodinamika [Sociodynamics], 5, 114-122. Available at: https://nbpublish. com/library_read article.php?id=15320

Kimeev, V.M. (2008). Ekomuzei Sibiri kak centry sokhraneniia i vozrozhdeniia istoriko-kul'turnogo i prirodnogo naslediia [Ecomuseums of Siberia as centres for the preservation and revival of historical, cultural and natural heritage]. In Etnograficheskoe obozrenie [Ethnographic Review], 11. Available at: http://journal.iea.ras.ru/online/2008/EOO2008_5b.pdf

Klimova, S.G. (2000). Stereotipy povsednevnosti v opredelenii 'svoikh' i 'chuzhikh' [Stereotypes of everyday life in the definition of "friends" and "foes"]. In Socis [Socis], 12, 13-22.

Koptseva, N.P. (2014). Ekspertnyi analiz osnovnykh tendentsii ekonomicheskogo razvitiia korennykh malochislennykh narodov Severnoi Sibiri. [Expert analysis of the main trends in the economic development of the indigenous peoples of Northern Siberia.]. In Economic Annals-XXI, 11-12, 93-96.

Koptseva, N.P., Amosov, A.E., Il'beykina, M.I., Evseenko, E.A. et al. (2018). Novye proekty dlia vozrozhdeniia evenkiiskogo iazyka $i$ kul'tury [New projects for the revival of the Evenki language and culture]. Krasnoyarsk, Siberian Federal University, 246 p.

Koptseva, N.P., Reznikova, K.V. (2015). Refinement of the causes of ethnic migration north Selkups based on the historical memory of indigenous ethnic groups Turukhansk district of Krasnoyarsk krai. In Bylye Gody, 38 (4), 1028-1038.

Korostina, T.V. (2000). Na puti k ekomuzeiu [On the way to the ecomuseum]. In Zapadnaya Sibir'. Istoriya i sovremennost': Kraevedch. zap. [Western Siberia. History and Present: Local Lore Notes]. Ekaterinburg, Sred.-Ural publishing house. 3, 28-31.

Krasovskaya, T.M., Tul'skaya, N.I. (2013). Kul'turnye landshafty aborigenov arktiki Rossii: identifikatsiia i kartografirovanie [Cultural landscapes of the natives of the Arctic of Russia: identification and mapping]. In Materialy Mezhdunarodnoi konferentsii "InterKarto. InterGIS" [Materials of the International Conference "InterCarto. InterGIS”], 19(1), 172-175. Available at: https://doi.org/10.24057/2414-9179-2013-1-19-172-175

Kurennoy, V. (2018). Granitsy v bezgranichnom mire [Borders in a limitless world]. Available at: https://www.goethe.de/ins/ru/ru/kul/sup/gre/aus/21288670.html

Leskova, I.V. (2009). Problema kul'turnoi identichnosti v situatsii krizisa tsennostei [The problem of cultural identity in a situation of a crisis of values]. In Vestnik RGGU. Seriia 'Filosofija. Sotsiologiia. Iskusstvovedenie' [Bulletin of the RSUH. Series 'Philosophy. Sociology. Art History]. 175-182.

Mannheim, K. (1991). Ideologiya i utopiya [Ideology and Utopia]. In Utopiya $i$ utopicheskoe myshlenie: antologiya zarubezhnoy literatury [Utopia and Utopian Thinking: An Anthology of Foreign Literature]. Moskow, Progress. P. 405.

Marx, K. (1974). Ekonomichesko-filosofskie rukopisi 1844 g. [Economic and philosophical manuscripts of 1844]. Moscow, Politizdat. 42, 41-174.

Nietzsche, F. (1990). Rozhdenie tragedii, ili ellinstvo i pessimizm [The birth of tragedy, or Hellenism and pessimism]. In Sochineniia $v 2 t$ [Works in 2 vols.], 1, 62. 
Novikova, N.I. (2013). Zashchita kul'turnogo naslediia korennykh malochislennykh narodov Severa v kontekste promyshlennogo osvoeniia [Protection of the cultural heritage of the indigenous peoples of the North in the context of industrial development]. In Vestnik Novosibirskogo gosudarstvennogo universiteta. Seriia: Istoriia. Filologiia [Bulletin of Novosibirsk State University. Series: History. Philology], 12(3), 93-101.

Ol'zina, R.S. (1997). «TORUM MAA»: ego proshloe i nastoiashchee ["TORUM MAA": its past and present]. In Tezisy dokladov $i$ soobshheniy nauchno-prakticheskoyj konferentsii "Slovcovskie chteniya -96" [Abstracts of reports and messages of the scientific and practical conference "Slovenian Readings -96"]. Tyumen, 29-31.

Pimenova, N.N. (2014). Kul'turnoe nasledie korennykh malochislennykh narodov Krasnoyarskogo kraia i sovremennye kul'turnye praktiki [The cultural heritage of the indigenous peoples of the Krasnoyarsk Territory and modern cultural practices]. In Chelovek $i$ kul'tura [Man and Culture], 2, 28-66. Available at: https://nbpublish.com/library_read_article. php?id=11269

Plotnikov, N. (1994). Reabilitatsiya istorizma. Filosofskie issledovaniia Germana Lyubbe [The rehabilitation of historicism. Philosophical studies of Hermann Lübbe]. In Voprosy filosofii [Issues of Philosophy], 4, 87-93.

Pospelova, A. I. (2000). Traditsionnye kul'tura i religiia avtokhtonnykh arkticheskikh narodov [Traditional culture and religion of the autochthonous Arctic peoples]. Saint Petersburg, $184 \mathrm{p}$.

Reznikova, K.V. (2015). Sokhranenie traditsionnykh iazykov korennykh malochislennykh narodov kak obespechenie osnovy kul'turnogo raznoobraziia regiona [Preservation of the traditional languages of indigenous peoples as providing the basis for the cultural diversity of the region]. In Sovremennye problemy nauki i obrazovaniia [Modern problems of science and education]. 1-1.

Rittser, D. (2011). Makdonal'dizatsiia obshhestva 5 [McDdonaldization of society 5]. Moscow, Praksis. 592 p.

Rumyantseva, M.V. (2016). Odo Markvard: skepsis i soglasie [Odo Marquard: Skepticism and Consent]. In Logos [Logos], 26(4), 165-180.

Rumyantseva, M.V. (2015a). Kompensatornaia teoriia v rabotakh Germana Ljubbe i Odo Markvarda [Compensatory theory in the works of Hermann Lübbe and Odo Marquard]. In Vestnik Leningradskogo gosudarstvennogo universiteta im. A.S. Pushkina [Bulletin of the Leningrad State University. A.S. Pushkin], 140-150.

Rumyantseva, M.V. (2015b). Reaktsiia na modernizatsiiu: otkaz ot moderna ili ego istorizatsiia? [Reaction to modernization: refusal of modernity or its historicising?]. In Vestnik SamGU [Bulletin of SamSU], 4 (126), 166-173.

Rumyantseva, M.V. (2017). Kontseptsiia moderna v shkole Ioakhima Rittera [The concept of Art Nouveau at the school of Joachim Ritter]. Moskow, $181 \mathrm{p}$.

Schlegel, K.V.F. (2015). Filosofiia zhizni. Filosofiia istorii [Philosophy of life. Philosophy of history]. Moscow, Quadrivium, $816 \mathrm{p}$.

Sztompka, P. (1996). Sociologiia sotsial'nykh izmenenii [Sociology of social change]. Moscow, Aspekt-Press, 415 p.

Shul'gina, D.N. (2010). Krizis kul'tury i identichnosti cheloveka v usloviiakh globalizatsii [The crisis of culture and human identity in the context of globalization]. In Vestnik VGU. Seriia: Filosofiia [Bulletin of Voronezh State University. Series: Philosophy], 173-180.

Tokarev, S.A. (1976). Religiia $v$ istorii narodov mira [Religion in the history of the peoples of the world]. Moscow, 487p.

Tul'chinskiy, G.L. (2002). Postchelovecheskaia personologiia. Novye perspektivy svobody $i$ ratsional'nosti [Posthuman personology. New perspectives of freedom and rationality]. St. Petersburg, Aleteya, $181 \mathrm{p}$. 
Welsch, W. (1992). "Postmodern". Genealogiia i znachenie odnogo spornogo poniatiia [Postmodern. Genealogy and the meaning of a controversial concept]. In Put'. Mezhdunarodnyy filosofskiy zhurnal [The Way. International Philosophical Journal], 1, 129-130.

Yadov, V.A. (2006). Sotsial'naia identifikatsiia v krizisnom obshchestve [Social identification in a crisis society]. In Sotsiologicheskiy zhurnal [Sociological Journal]. Available at: http://www. socjournal.ru/article/29

Zamaraeva, Yu.S., Luzan, V.S., Metlyaeva, S.V., Seredkina, N.N., Koptseva, N.P., Fil'ko, A.I., Khrebtov, M.Ya. (2019). Religion of the evenki: history and modern times. In Zhurnal SFU. Gumanitarnye nauki [Journal of SibFU. Humanities \& Social Sciences], 12 (5), 853-871.

\title{
Компенсаторная роль символических медиаторов в конструировании этнокультурной идентичности
}

\author{
Ю.Н.Авдеева, К.А. Дегтяренко, Н.П. Копцева \\ Сибирский федеральный университет \\ Российская Федераичи, Красноярск
}

\begin{abstract}
Аннотация. Статья посвящена исследованию проблем культурной идентичности в условиях современных глобальных трансформаций. Сделан аналитический обзор концепций зарубежных и отечественных исследователей, связанных как с негативной, так и с позитивной оценкой влияния гипердинамизма современного развития на формирование идентичности. Проанализирован феномен «историзации культуры», отражающий значимость обращения к истокам для преодоления проблемы отчуждения, одиночества, увеличивающегося разрыва с прошлым, утраты преемственности поколений. Рассмотрена теория компенсаций и теория памяти, которые предлагают конкретные культурные формы репрезентации истории, играющие неоценимую роль в становлении и поддержании этнокультурной идентичности.
\end{abstract}

Ключевые слова: этнокультурная идентичность, культурный универсализм, символические медиаторы, компенсаторная теория, историзация культуры, глобализация, теория памяти, музеизация.

Исследование выполнено при финансовой поддержке РФФИ в рамках научного проекта № 19-39-90012.

Научная специальность: 24.00.00 - культурология. 